\title{
Landsekap Pertamanan: Kajian Atas Data Tekstual
}

\section{Fadhila Arifin Aziz}

Keywords: landscape, garden, inscription, text sources, philology

\section{How to Cite:}

Aziz, F. A. Landsekap Pertamanan: Kajian Atas Data Tekstual. Berkala Arkeologi, 14(2), 27-30. https://doi.org/10.30883/jba.v14i2.637

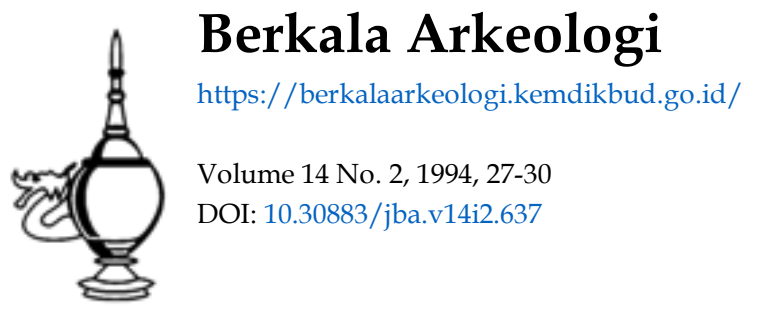

\section{cc) (i)(2)}

This work is licensed under a Creative Commons Attribution-NonCommercial-ShareAlike 4.0 International License. 


\title{
LANDSEKAP PERTAMANAN: KAJIAN ATAS DATA TEKSTUAL
}

\author{
Fadhila Arifin Aziz \\ (Pusat Penelitian Arkeologi Nasional)
}

\section{Pendahuluan}

Pemanfaatan data tekstual dapat dianggap sebagal bukti kesaksian budaya yang sesuai dengan peristiwa dan keadaan pada masa itu. Data tekstual berupa prasasti sebagai sumber sejarah tertulis dapat pula dianggap merupakan refleksı fakta sosıal yang bersumber dari gagasan (kognısi) maupun perilaku kolektif suatu kelompok masyarakat dengan latar budaya tertentu. Penelusuran dan pengkajian yang mendalam terhadap is prasasti akan memperkaya baik pengetahuan epigrafi itu sendiri maupun sejarah Indonesia kuna

Dalam prasasti biasanya dijumpai data mengenai pertanggalan, nama raja yang mengeluar kan prasastı dan pejabat tingginya, dan penetapan sima. Pada beberapa prasasti ditemukan penyebutan nama pejabat yang membuat dan memelihara taman dikaitkan dengan konsepsi religius khususnya agama Buddha Mahayana. Kajian data tekstual yang berkaitan dengan penelusuran aspek penataan taman sampai kini sangat jarang dibahas. Pakar epigraf asing seperti De Casparis (1990) telah merintis pembahasan taman kuno yang ada di Sumatra barat berdasarkan data prasastı Oleh karena itu dalam penulisan ini dicoba mengkaji secara ekstern data tekstual (prasasti) yang menyebutkan taman dengan menggunakan pendekatan landsekap pertamanan.

\section{Landsekap Pertamanan dalam Arkeologi}

Pengertian 'taman' dalam Arkeologi diartkan sebagai taman asli yang ada pada masa lalu, ataupun taman yang dibuat pada masa kini dengan memilih situs sebagai lokasi. Pada masa kını pembuatan taman purbakala bertujuan selain untuk mempertahankan nilai keaslian tinggalan arkeologi, juga digunakan bagi kepentingan ilmu pengetahuan, pariwisata, sarana pengembangan pendidikan, dan penelitian Arkeologi murni (Mundardjito, 1984; Hari Untoro Drajat, 1992)

Pada dasarnya per:ibuatan sebuah taman bertujuan untuk keindahan, disamping untuk menghilangkan rasa lelah dan memperoleh udara segar. Perkembangan selanjutnya taman dibangun sebagal tempat pemanfaatan ruang yang didasarkan pada konsepsi keselarasan dan keserasian dengan lingkungan sekitamya. Pemanfaatan ruang sebagai taman dapat pula merupakan bentang alam terbuka ataupun ruang tertutup. Selaın Itu, wujud taman dapat merupakan cermın sejarah masa lalu yang berkaitan dengan konsepsi adanya keselarasan antara lingkungan alam dengan manusia
Adapun Landsekap diartıkan sebagaı keseiuruhan lingkungan hidup organısma dan merupakan totalitas ruang yang dapat dihayatı, diraba dengan panca indera, serta dimanfaatkan untuk kebutuhan tertentu. Bila ruang yang ditata dan dimanfaatkan berdasarkan azas harmonıs, keselarasan, dan keseımbangan diisı dengan jenıs tanaman tertentu maka biasanya dikenal sebagai landsekap pertamanan Jenis tanaman dapat $d_{i}$ kategorıkan antara lain darı tumbuhan golongan pohon-pohonan semak/perdu, ataupun tumbuhan kecil yang mengandung banyak air dan sedikıt zat kayu (herba) Dengan demikian landsekap pertamanan menyangkut masalah penataan lokasi dan pemilihan jenis-jenıs tanaman tertentu yang dapat dibuat baik secara alamı maupun berlatar konsep budaya. Dalam artian luas landsekap pertamanan dapat ditınjau darı bentuk fisık dan kegunaannya Meskipun demikian konsep penataan ruang berbeda-beda sesual dengan lingkungan dan latar sosıal budaya masyarakat pendukungnya

\section{Data Tekstual Tentang Landsekap Pertamanan}

Pada masa pengaruh budaya bercorak Hindu-Budha di Indonesıa, pembuatan taman tidak bisa lepas darı bangunan keagamaan. Bangunan tertua di wilayah Nusantara ditemukan pada abad $6 \mathrm{M}$. Dalam agama Buddha, taman dianggap sebagai salah satu unsur pemukıman yang berfungsi sebagai tempat melaksanakan kegiatan keagamaan dan meditasi (Richadiana, 1991:248) Mitologi agama Buddha menyebutkan Buddha Gautama mengajarkan agama Buddha untuk pertamakali di taman Mrgadawa. Pokok ajaran (dharma) Buddha Gautama sebagai inti ajaran agama Buddha adalah pencapaian kebenaran mulia Untuk mencapal kebenaran mulia tersebut melaluı Jalan pelepasan (marga), yaitu samadh. Dalam menjalankan samadhi inı dibuat bangunan sucl dengan taman (ksetra). Disamping itu, pada tempat inı terdapat arca Buddha atau Bodhisatva, stupa, vihara, dan telaga (petirtaan).

Menurut Boecharı (1980:321), tanah-tanah yang dıjadıkan sima dapat berupa sawah, ladang. kebun, pagagan, padang rumput, taman, daerah perumahan, hutan, rawa-rawa, dan sungai. Selaın itu, dalam prasasti masa Jawa Kuno dijumpai is. tilah mataman. yaitu pejabat yang mengurusı taman (Boecharı, 1986:7). Pada beberapa prasastı ditemukan pula kosa kata kebun (kbun kbuan) Adanya jabatan tersebut memberikan gambaran bahwa ada orang yang memiliki keahlian mengurus taman atau kebun 
Sehubungan dengan profesi di atas, beberapa pertanyaan yang muncul antara lain bagaimanakah masyarakat bercorak budaya HinduBuddha mengelola tamannya? Dimana diletakkan kebun dalam suatu setting pemukiman? Bagaimana pola pemilikannya? Sejauhmana peran dan pola kerja pengelola taman dalam perencanaan atau pembuatan suatu taman? Apakah ada diferensiasi sosial dan penampilan taman bagi kebutuhan kalangan istana dengan rakyat umum?

Kerajaan Sriwijaya sebagai suatu pusat pengembangan Agama Buddha tentunya memiliki tempat yang dikeramatkan bagi umat agama Buddha dalam melakukan siddhayatra maupun tirthayatra Salah satu prasasti terlengkap dari masa Jayanasa (abad VII--VII M), yaitu Talang Tuo yang ditemukan di Desa Talang Tuo, Kecamatan Talang Kelapa, Palembang. Teks prasasti beraksara pallava dan berbahasa Melayu kuna, ini terdiri da" 14 baris, dipahatkan pada sebongkah batu berukuran $50 \times 80 \mathrm{~cm}$. Isi prasasti menyebutkan tentang pembuatan taman Sri Ksetra pada 606 C yang dipımpın oleh Srı Jayanasa. Taman yang mempunyal pemandangan indah ini diduga dibangun di tepı sebelah utara Sungai Musi, ditujukan bagı kepentıngan rakyat dan merupakan janji suci seorang calon yang akan mencapai bodhi (pranidhana) (Casparıs, 1990:Richadiana, 1991).

Dalam prasasti Talang Tuo disebutkan pula berbagai jenıs tanaman yang telah ditanam, antara laın darı jenıs pohon-pohonan (buah) seperti kelapa pınang, aren, sagu (tumbuhan yang ternasuk dalam famili Palmae), jenıs tumbuhan bambu (haur wuluh betung) (tumbuhan dari famili Graminae). Telaga/kolam, hewan, dan pengelolaan taman Penanaman jenis pohon diatas bertujuan sebagaı tempat peneduh, pelepas lelah, penawar danaga, dan penghilang lapar bagi para pelancong Berdasarkan uraian di atas, taman Srı Ksetra sengaja dibuat seindah dan senyaman mungkın bagı kesejahteraan masyarakatnya (Coedes, 1989, Rıchadiana. 1992).

Hasıl anailsa terhadap fosıl serbuk sarı pada contoh tanah antara lain dari Familia $A n$ nonaceae banyak ditemukan, sedangkan Lycopodiaceae Plantaginaceae. Cyperaceae, dan Thymelaceae sedikit ditemukan. Banyaknya famili Annonaceae merupakan indikasi bahwa tumbuhan in dapat hıdup dan berkembang dengan baik. Familia di atas merupakan keluarga besar dari tumbuh-tumbuhan berbuah yang tersebar di daerah tropis: seperti srikaya (Annona squamosa), sırsak (Annona muricata), buah nona (Annona retıculata), dan kenanga (Cananga odorata). Tumbuhan buah-buahan yang disebut dalam prasasti darı famili Paimae antara lain sepertı kelapa, sagu dan pınang tidak berhasil ditemukan fosil serbuk sarınya. Meskıpun demıkıan diduga dari fosı serbuk famili Palmae yang ditemukan kemungkinan jenis tumbuhan aren (Arenga pınnata), dan famili Gramineae adalah jenis tumbuhan bambu (Bambusa sp.). Selain itu juga dijumpai jenıs tumbuhan dari famili Lycopodiace sepertı jenis terong, tomat, paku-pakuan, dan bangsa herba dengan batang pejal (Cyperaceace) seperti tek rawa.

Saat ini daerah ini didominasi oleh tumbuhan alang-alang (imperata cylindrica), senduduk (Melastoma malabatricum), Brugerra sp, jambu biji (Psidium guajava), pepaya (Carica papa$y a)$, aren (Arenga pinnata), bambu betung (Bambusa sp.), dan jambu (Syzigrum sp.). Tumbuhan buah-buahan di atas sengaja ditanam masyarakat sekarang, sedangkan aren dan bambu betung merupakan tanaman liar yang biasanya hıdup dı daerah rendah. Diduga lebih dominannya tumbuhan alang-alang dan senduduk menunjukkan peralihan dari ekosistem padang rumput tanah rendah menjadi ekosistem belukar (Aifian, 1990:6-12)

Hingga kini belum diketahui fungsi laın darı pembangunan Taman Srikesetra. Adapun Jenıs tumbuh-tumbuhan di atas tentunya juga sebagai penahan air hujan agar tidak terjadi erosi. Morfologi daerah Situs Talang Tuo relatif datar oleh karenanya mungkin merupakan daerah terjadinya erosı. Selain itu, pembangunan telaga/kolam kemungkinan bertujuan untuk penyediaan air bersih

Meskipun demikıan ide pendirıan monumen dan taman purbakala Kadatuan Sriwijaya baru muncul pada tahun 1989. Lokası yang dipılih untuk taman adalah Desa Karanganyar. sebelah barat Kota Palembang, berupa bangunan air (kolam dan parit). Pada lokasi ini ditemukan Prasasti Bukit Siguntang (682 M) yang menyebutkan pendiri Kadatuan Sriwijaya melakukan perjalanan untuk mencapai siddhayatra

Raja Adityawarman yang bergelar Surawasan (1345--1375 M) di Sumatera Barat pernah membangun taman (hutan) yang indah di dekat Suruaso. Hal tersebut didasarkan pada Prasastı Bandar Batu Bapahat yang menggunakan bahasa Sanskrta dan Tamil. Menurut pembacaan $\rfloor G$ de Casparis, hutan Nandana (Nandanawana ?) yang bernama Sri Surawasa (kinı berubah nama menjadi Suruaso) diduga terletak tidak jauh darı Batu Sangkar (Pagaruyung) ditanamı tanaman yang berbau harum seperti melatı (jasmın) dan ketaka (Pandanus Odoratissımus). buah-buahan sepertı kelapa, mempelam, dan jambu. Ditengah-tengah taman terdapat kolam dengan bunga terataı berwarna merah (padma), putih (kumuda), dan tempat mandi dengan pancuran aır (Casparıs 1989) Sayang sekail pengujlan serbuk pollen sampa kıni belum dilakukan dı Situs Suruaso

Dalam Naskah Calon Arang darı masa pemerintahan Asriangga disebutkan bahwa Mp. 
Bharada memerintahkan muridnya melakukan penghıjauan dengan menanam tumbuh-tumbuhan seperti angsoka, nagasari, melatı, gambir, kembang sepatu, pacar cina di sekeliling pertapaan (Poerbatjaraka, 1982; Richadiana, 1990) Bukti-bukti arkeologis menunjukkan bahwa Raja Airlangga yang banyak membuat waduk untuk mengairi sawah dan ladang. sangat memperhatikan pelestarian lingkungan dan kesejahteraan rakyatnya

Selanjutnya dalam naskah Nagakretagama disebutkan bahwa pujangga Prapanca melancong ke taman bertingkat untuk melepaskan lelah dan melupakan segala duka. Pada taman ini selain bunga-bungaan seperti nagakusuma, juga ditumbuhı kepala gading kuning, andung, menur, karawira, kayu puring dan kayu mas. Di taman ini terdapat pesanggrahan dan pemandian dengan lukisan dongengan (pupuh $X X X \|$, bait 3-5, Slametmulyana, 1979:288--289)

Pada masa pengaruh budaya Islam, pendirian taman tetap dikaitkan dengan kompleks bangunan istana. Contoh yang masih dapat diamati antara lain taman ghairah dalam naskah Bustan us Salatin darı masa Sultan Iskandar Muda (1607. 1636 M), taman Tasık Ardi yang dibuat pada masa Sultan Ageng Tirtayasa (1651-1682 M), taman Sari yang dibangun tahun 1758 M, dan taman Sunyaragı yang dibangun pertamakali oleh Pangeran Mas Panembahan Ratu I pada abad 1549. Taman menjadi sarana tempat beristirahat dan mensucikan diri. Beberapa contoh taman seperti di Tasık Ardı dan Sunyaragi bentuknya menjadi lebih kompleks yaitu merupakan gabungan danau buatan dengan pulau ditengahnya. Sistem sirkulasi air melalui pancuran berhias, ataupun kombınasi gugusan bangunan peristirahatan dengan gua-gua batu karang. Disamping itu motif hiasan tampaknya melanjutkan tradisi Hindu-Buddha berupa gunung awan dan flora - fauna yang distilir dengan berlandaskan alam pıkiran kosmologıs

Penutup

Berdasarkan uraıan dı atas dapat disimpulkan bahwa manusıa masa lalu tampaknya sudah memilikı pemahaman dan penafsiran pentıngnya keseımbangan lingkungan dalam pendirıan suatu bangunan. Dalam kajian data tekstual (prasasti), bentuk taman disampıng berfungsi sebagai pelengkap keındahan suatu pemukiman seperti candi, juga merupakan bagıan dari perjalanan pencaparan kebenaran dalam inti ajaran agama Buddha. Kontinuitas nilai budaya yang mengandung makna keselarasan dan keseımbangan antara aspek estetika, konsepsı religius, dan lingkungan sekitar pada masa budaya corak Hındu-Buddha. Di masa sekarang kemudian berkembang sebagai landsekap pertamanan dengan cakupan aspek yang lebih luas
Oleh karena itu dalam perencanaan sebuah taman purbakala nasional, luas lahan dibagi atas zona lahan situs (sanctuary area), zona lahan fasilitas (facility area), dan zona penyangga (buffer zone). Adapun tamannya sendiri (gardens) biasanya dibangun di zona lahan fasilitas, di samping bangunan lain seperti parkir, pusat informasi, toko cinderamata, dan museum. Gambaran di atas dapat dilihat secara jelas pada taman purbakala nasional, seperti Situs Sumpangbita 'Sulawesi Selatan), Situs Karanganyar (Palembang), Situs Cipari (Kuningan), dan sebagainya (Harı Untoro Drajat 1992; Mundardjito 1993).

\section{KEPUSTAKAAN}

Anwar Falah, 1983. Bangunan Purbakala Sunyaragi (Cirebon): Sebuah Tinjauan Guna dan Gaya Seni Bangunan. Skripsi Sarjana Sastra Universitas Indonesıa

Arfian, S. 1990. Analisis Pollen Sedimen Situs Talang Tuo dan Bukit Seguntang, Kotamadya Palembang, Sumetera Selatan Jakarta. Puslit Arenas.

Bambang Budi Utomo 1992, Taman Purbakala Kadatuan Sriwijaya di Palembang, PIA VI Malang, Juli: hlm. 104--112 (belum terbit)

Boechari, 1986, Kerajaan Mataram Sebagaimana Terbayang Dari Data Prasasti, makaIah dalam Ceramah di Museum Nasıonal Jakarta, 1 November.

1980. Candi dan Lingkungannya dalam PIA I, hIm. 319-341

Coedes, G.: 1989, Prasastı Berbahasa Melayu Kerajaan Sriwijaya, dakam Kedatuan Sriwıjaya: Penelitian Tentang Sriwijaya Jakarta: Depdikbud., hlm. 47--110

De Casparis, J. G., 1990 An Ancient Garden in West Sumarra, dalam Kalpataru, no 9 Jakarta: Depdikbud him 40--49

1989. Peranan Adityawarman. Seorang Putera Melayu di Asıa Tenggara, makalah dalam Persidangan Antara bangsa Tamadun Melayu ke II, Malaysıa 15--20 Agustus

Hari Untoro Drajat 1992. Pelestarian dan Pemanfaatan Situs, makalah dalam Diskusi IImiah Arkeologi ke-8, Jakarta. 6-? Julı 
Marıa Rosita, Priıoharıjono, 1990, Arsitektur Jawa Pada Masa Majapahit: Suatu Tinjauan terhadap Identifikasi Bangunan Tempat Tinggal dan Kaitannya dengan Stratifikasi Sosial, Yogyakarta: Proyek Javanologı, Depdikbud.

Mundardjito, 1984, Lingkungan Hidup dan Kebudayaan Masa Lalu, makalah dalam Kursus Dasar-dasar Analisis Dampak Lingkungan, 6--12 Maret.

Noerhadi Magetsarı,1981, Agama Buddha Mahayana di Kawasan Nusantara, Seri Penerbitan IImiah, Jakarta: FS-UI, hIm $\quad 1-35$

Slametmulyana, 1979, Nagarakretagama dan Tafsir Sejarahnya, Jakarta, Bhratara.

Teguh Asmar. 1977, "Taman Purbakala Sebuah Cara untuk Pengembangan Situs Arkeologi“, dalam Seminar Arkeologi, Cibulan, Proyek Pelita Pengembangan Media Kebudayaan Departemen Pendidikan dan Kebudayaan, Jakarta, him. 153--159

Rıchadiana Kartakusuma, 1990. Konsepsi dan Pelestarian Hutan bagi Masyarakat Jawa Kuno dalam Proceedings AHPA III: Kajian Agrikultur Berdasarkan Data Arkeologi. Departemen Pendidikan dan Kebudayaan, Jakarta, hlm. 123-134.

1992. Prasastı Talang Tuwo: Kultus Dewaraja. PIA VI. hlm. 241-250 (belum terbit) 